Año XLIX. urtea

$123-2017$

Urtarrila - ekaina

Enero - junio

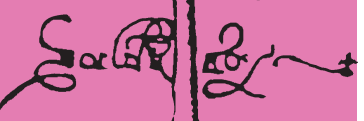

然
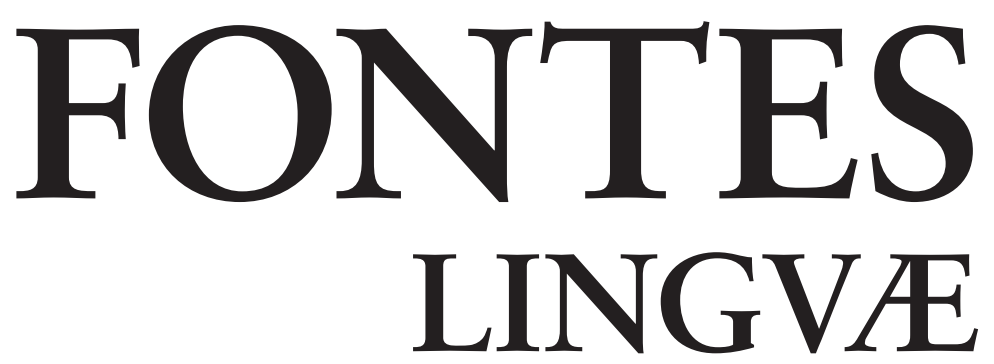

VASCONVM

STVDIA ET DOCVMENTA

SEPARATA

\title{
Azpeitiko azentuaren gauzatze fonetikoaz
}

José Ignacio Hualde, Ander Beristain

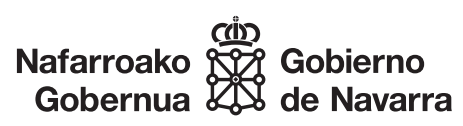

0000 


\title{
Azpeitiko azentuaren gauzatze fonetikoaz
}

\author{
Sobre la realización fonética del acento en el euskera de Azpeitia
}

On the acoustic realization of stress in Azpeitia Basque

José Ignacio HUALDE

Department of Spanish and Portuguese \& Department of Linguistics

University of Illinois at Urbana-Champaign

jihualde@illinois.edu

Ander BERISTAIN

Department of Spanish and Portuguese

University of Illinois at Urbana-Champaign

anderb2@illinois.edu

Gure esker ona adierazi nahi diegu eskuizkribua ebaluatu eta iruzkindu duten irakurleei; Chris Eager-i, datu akustikoak ateratzeko erabili dugun Praat script-a idazteagatik; Joe Roy-ri analisi estatistikoarekin aholkuak emateagatik; Lierni Varelari estilozko zuzenketak proposatzeagatik; eta, azkenik, esperimentuan parte hartu duten azpeitiarrei ere bai. 


\section{LABURPENA}

Lan honetan, Azpeitiko hizkeraren azentuaren ezaugarri akustikoak aztertzen ditugu. Singular/plural hitz pareak erabili ditugu bokal azentudunen eta azentugabeen arteko diferentzia akustikoak miatzeko. Emaitzek erakusten dute tonuak eta intentsitateak azentu-gunea adierazten dutela. Bereziki, aztertu dugun testuinguruan, silaba azentudunek tonu gorakada erakusten dute. Iraupena, alderantziz, ez da erabiltzen azentuaren ezaugarri esanguratsu bezala. Emaitza hauek beste euskal hizkera batzuen datuekin konparatzen ditugu eta iraupenaren azentuzko erabilerak bokalen galera gertakarietan izan dezakeen eragina kontsideratzen dugu.

Gako hitzak: azentuaren ezaugarri akustikoak; oinarrizko maiztasuna; intentsitatea; iraupena.

\section{RESUMEN}

En este artículo se describe un experimento acerca de los correlatos acústicos del acento en el euskera de Azpeitia (Gipuzkoa). En nuestro experimento utilizamos pares mínimos singular/plural para examinar la diferencia acústica entre vocales tónicas y átonas. Tanto el tono como la intensidad indican la posición del acento. En concreto, en el contexto examinado, las sílabas tónicas presentan una subida tonal. Por otra parte, no encontramos un efecto significativo de la duración como correlato acentual. Comparamos estos resultados con los obtenidos sobre otras variedades vascas y discutimos la posible relación entre el uso acentual de la duración vocálica y fenómenos de elisión de vocales.

Palabras clave: correlatos acústicos del acento; frecuencia fundamental; intensidad; duración.

\section{ABSTRACT}

We report on an experiment on the acoustic cues of stress in the Basque variety of Azpeitia. We use singular/plural minimal pairs to examine acoustic differences between stressed and unstressed vowels. Both pitch and intensity appear to cue lexical stress. In particular, in the context that we have examined, stressed syllables show a pitch rise. On the other hand, we did not find a significant effect of vowel duration as a cue to stress. We compare these results with work on other Basque dialects and offer some speculation on the relationship between the role of duration as a cue to stress and phenomena of vowel deletion.

Keywords: Acoustic correlates of stress; fundamental frequency; duration; intensity. 
1. SARRERA. 2. EUSKAL AZENTUAREN IZARI AKUSTIKOAK. 3. AZPEITIKO AZENTUAZIOA: ARAUAK. 4. IKERKETA-GALDERAK. 5. METODOAK. 5.1. Estimuluak eta parte-hartzaileak. 5.2. Grabaketa eta analisi akustikoa. 6. HiPOTESIAK. 7. EMAITZAK. 7.1. Estatistika deskribatzaileak. 7.2. Estatistika inferentzialak. 8. LABURPENA. 9. ONDORIOAK: EUSKAL AZENTUAREN BILAKAERA ETA SEGMENTU-FONOLOGIA. 10. ERREFERENTZIAK.

\section{SARRERA}

Lan honetan gure xedea euskal hizkera jakin baten azentuak zer ezaugarri akustiko dituen aztertzea da. Hain zuzen ere, Azpeitiko euskararen azentua dugu aztergai. Azterketa honen bidez, beraz, ekarpen bat egin nahi dugu euskararen egitura prosodikoaren ikerketa-arlora. Bestalde, neurri txikian bada ere, azentuari lotutako zenbait gertakari argitzen saiatu nahi dugu.

Jakina denez, euskal hizkerak erkatzen ditugunean, oso dibertsitate handia aurkitzen dugu hitz mailako prosodiari dagokionez (Gaminde, 1998; Hualde, 1997, 1999); azentu-sistema ugari ditugu -nahiz eta posible den berreraiketaren bidez denak diakronikoki lotzea (cf. Egurtzegi \& Elordieta, 2013; Elordieta, 2011b; Hualde, 2003, 2006, 2014; Hualde, Elordieta, Gaminde \& Smiljanić, 2002).

Elkarrengandik urrun dauden bi eskualde desberdinetan, hots, Bizkaiko kostaldean eta Nafarroako ipar-mendebaldean, doinu-azentu sistemak ditugu gaur egun. Bi doinu-azentu sistema horiek desberdinak dira: Bizkaiko kostaldean, hitzak azentudunak edo azentugabeak izan daitezke (Azkue, 1931, 1932; Elordieta, 1997; Gaminde, 1995; Hualde, 1991: 140-168, 1997, 1999; Hualde \& Bilbao, 1992; Hualde, Elordieta \& Elordieta, 1994; Jacobsen, 1992; Jun \& Elordieta, 1997), Tokyoko japonieran bezala (Haraguchi, 1977; Kubozono, 1993; Pierrehumbert \& Beckman, 1988). Goizuetan eta inguruko beste hizkera nafar batzuetan, aldiz, hitz guztiak azentudunak dira, baina batzuek goranzko tonua daramate eta beste batzuek, beheranzkoa (Hualde, Lujanbio \& Torreira, 2008). Hizkera horretan, azentu-sistemak antzekotasun handiagoa erakusten du Europako beste doinu-azentu sistema batzuekin, hala 
nola suediera-norvegierarekin (ikus Bruce, 1977; Riad, 2012), Rhin aldeko hizkera behe-germaniarrekin (ikus Gussenhoven, 1999, 2000, 2004, 12. kap.), letonierarekin (ikus Hualde \& Riad 2014; Kariňš, 1997) eta serbiera-bosniera-kroazieraren hizkera batzuekin (Bethin, 1998; Godjevac, 1999; Smiljanić, 2006) eta antzinako grezierak (Horrocks, 1997) omen zuen doinu-azentu sistemarekin.

Gainerako euskal hizkeretan horrelako doinu-azentuzko gertakaririk aurkitu ez bada ere, azentua kokatzeko arauak oso desberdinak izan daitezke hizkera batetik bestera. Adibidez, Bergaran, Baztanen eta Zuberoan, azentua, orokorrean, azken-bigarren silaban doa (adib., Bergarakúa). Haatik, Gipuzkoako eta Bizkaiko leku askotan, bigarren silaban doa (adib., Oñátikua). Azkenik, hemen aztergai dugun Urolaldeko hizkeretan, hirugarren silaban kokatzen da oro har (adib., Azpeitíkue). Honetaz gain, euskal hizkera batzuetan azentuaren kokagunea adiera desberdineko hitzak bereizteko erabiltzen da, eta beste batzuetan ez. Azpeitiko hizkerak azentu bereizgarria du, adib., básue da 'edalontzia' vs basué da 'oihana'; lagunén etxié da 'lagunaren etxea da' vs lagúnen etxié $d a$ 'lagunen etxea da'. Beraz, euskal azentueren artean desberdintasunak aurkitzen ditugu, bai azentu-arauetan, baita azentuaren balio fonologikoan ere.

\section{EUSKAL AZENTUAREN IZARI AKUSTIKOAK}

Azentua kokatzeko arauetan bezala, azentuaren gauzatze fisikoan ere badira alde handiak euskal hizkeren artean; baina gai honetaz informazio gutxiago dugu, argibidea izateko analisi akustikoa egin behar baita.

Hasteko, aipatu ditugun bi doinu-azentu motak, Bizkaikoa eta Nafarroakoa (Goizueta ingurukoa), oso desberdinak dira alderdi honetan ere. Goizuetan tonuak garrantzi handia du, baina silaba azentudunak erakusten duen tonu-mugimendua desberdina da klase prosodikoaren arabera: hitz batzuetan goranzko mugimendu bat dago silaba azentudunean, eta beste hitz batzuetan, berriz, beheranzko mugimendua. Adibidez, datibo singularrean ardíri 'ardiari' esaten da, goranzko tonuarekin, eta pluralean, aldiz, ardiri 'ardiei', beheranzkoarekin, edo beste adibide bat litzateke arrántza 'astoaren arrantza' eta arràntza 'arrantzaleen arrantza'. Tonu gorabeherak gorabehera, silaba azentuduna beti da alboko azentugabeak baino luzeagoa. Iraupenak argi adierazten du silaba azentuduna zein den, bokal azentudunak asko luzatzen baitira (Hualde, Lujanbio \& Torreira, 2008).

Iraupenari dagokionean, beste muturrean, Bizkaiko kostaldeko azentuazioa dugu. Sistema prosodiko honen ikerketa akustikoak erakutsi digu iraupena ez dela (ia) erabiltzen azentuaren ezaugarri gisa. Hizkera horietan, tonua da azentuaren ezaugarri nagusi eta, funtsean, bakarra (ikus, adib., Gaminde, 1993). Silaba azentudunek eta azentugabeek, aldiz, antzeko iraupena dute (Elordieta \& Hualde, 2003a; Hualde, Cole \& Smiljanić, 2000). Lehen esan bezala, eskualde horretan hitz azentudunen eta azentugabeen arteko aurkaritza bat aurkitzen dugu (adib. Lekeitio lagunen alabiá, azentu bakar batekin, 'lagunaren alaba' vs lagúnen alabiá, bi azenturekin, 'lagunen alaba'). Azentua tonuaren bidez adierazten da: tonu-gailurra silaba azentudunean dugu eta tonu-beherakada azkarra hurrengo silaban. Beraz, hitz batzuek berez dute tonu-mugimendu bat 
(hitz azentudunek) eta besteek ez (hitz azentugabeek). Hau da azentuera horren ezaugarri nagusi eta aipagarriena.

Alderdi hau zubereran aztertu zen beste euskalkietan baino lehenago. Larrasquet-ek (1928) zubereraz oinarrizko maiztasuna edo tonua azentuaren ezaugarri nagusia dela erakutsi zuen, baina, horretaz gain, intentsitatea eta iraupena ere azentuaren kokagunea identifikatzeko erabiltzen direla ere azaldu zuen. Gerora, Gamindek (1995a) deskribapen hori baieztatu egin zuen bere ikerketa batean, zubereraz egiten den 9 herritako hiztunen datu akustikoak aztertuta.

Gipuzkoako hizkeretako azentuak dituen ezaugarri fisikoez gutxiago dakigu, ordea. Gamindek (1995b) gipuzkeraz hitz egiten den 18 herritan bildutako datuak eskaintzen dizkigu, eta bertan, hizkeron sailkapen prosodiko bat proposatzen du. Artikuluan aztertzen duen izari akustiko bakarra oinarrizko maiztasuna da.

Gipuzkoako euskaran, oinarrizko maiztasuna aztertzeaz gain, beste izari edo dimentsio akustiko batzuk ere ikertzea interesgarria izan daitekeela uste dugu, bereziki, iraupena. Ikerketa hau deskribapen aldetik interesgarria izateaz gain, argigarria ere izan daiteke sinkopa- eta aferesi-fenomenoen genesi edo jatorria ulertzeko. Aferesi- eta sinkopa-fenomenoek azentuaren eragina erakusten dute, galtzen diren bokalak azenturik gabeko silabetan egoten baitira: aferesian, hitzaren hasierako bokal azentugabeak galtzen dira, eta sinkopan, hitzaren barneko bokal azentugabeak. Zehazkiago esanda, gertakari horiek azentuaren izaera fisikoarekin lotzen dira, eta, bereziki, iraupenak du garrantzia. Bokal azentugabeak oso laburrak baldin badira, erortzeko joera izango dute. Lehen esan dugunez, Goizuetako hizkeran iraupenak garrantzi handia du silaba azentuduna nabarmentzeko, eta beste hizkera nafar askotan bezala, aferesiak (adib; emán > mán, ikúsi > kúsi) eta sinkopak ugariak dira hizkera horretan (adib., meréndatu > beréndu, diférentzia > diféntzia, txokólate > txokòlte, etab., ikus Lujanbio, argitaratzeke).

Bokal azentugabeen galera ekialdeko edo Nafarroako fenomenoa da. Gipuzkoan eta Bizkaian (edo erdialdeko eta mendebaldeko euskalkietan, Zuazoren (2014) sailkapenean), aldiz, sinkopa- eta aferesi-fenomenoek ez dute indarrik. Azpeitian, kasu, emán esaten da, eta ez man, edota txokolátie esaten da, eta ez txokoltie. Gure hipotesia da iraupenaren eta azentuaren arteko loturak aferesi eta sinkoparako joeraren indarra baldintzatzen duela.

Aferesi- eta sinkopa-fenomenoetatik bereizi egin behar da bokal-sekuentzien sinplifikazioa, noski. Azken fenomeno hori Gipuzkoan eta Bizkaian ere ezaguna da, baita Bizkaiko kostaldeko doinu-azentuzko sistemetan ere. Hori horrela, ikus Getxo neskea $>$ neske edo Ondarroa neskie > neski (edo hedadura handiagoa duen, buruak > buruk, silaba hertsian edo kontsonante baten aurrean). Ohartu gaitezen hemen galtzen diren bokalak azentudunak izan daitezkeela. Beraz, azentuak ez ditu baldintzatzen bokal erorketa horiek, ekialdeko sinkopa-aferesietan ez bezala. Lan honetan aztertuko dugun Azpeitiko hizkeran ere horrelako bokal-sekuentzietan sinplifikazio fenomenoak aurkitzen ditugu, eta, batzuetan, azentu-aldaketa gertatzen da ondorioz, adib. etxiékin etxikin 'etxearekin'. 
Hori guztia kontuan izanda, Gipuzkoako hizkera jakin baten azentuaren adierazle akustikoak aztertzeari ekingo diogu jarraian. Analisi hau egiteko, Azpeitiko euskara aukeratu dugu. Bestalde, «sagarrak sagarrekin» konparatzeko, ingelesez esaten den bezala, neurri batean, Hualde, Lujanbio \& Torreiraren (2008) artikuluko esperimentu baten metodologia erabili dugu hemen ere. Esperimentua azaldu eta emaitzak adierazi baino lehen, Azpeitiko euskararen azentu-arauak zehaztuko ditugu laburki.

\section{AZPEITIKO AZENTUAZIOA: ARAUAK}

Azpeitiko euskarak azentu bereizgarria du; hau da, azentuaren kokagunea aldatu egin daiteke hitzen esanahiak bereizteko. Araurik orokorrena -hitz gehienei singularrean eta mugagabean aplikatzen zaiena- azentua hirugarren silaban kokatzea da, silaba hori hitz prosodikoaren azkena ez bada, behintzat: alkatíe, gizonána 'gizonarena', aldapákue, Azpeitíko (ikus Altuna, 1985; Hualde, 1997: 158-167, 1998; Beristain, prestatzen). Hitzak hiru silaba baditu, azentua azken-aurreko silabara atzeratzen da muga prosodiko baten aurrean, adib. gizoná da baina gizóna.

Hitz gehienen pluralean azentua silaba bat aurrerago doa: alkátiek (pl), gizónana 'gizonena'. 1. taulako adibideetan bi silabako eta hiru silabako izen bakoitzaren deklinabide partzialak erakusten dira adibide gisa.

1. taula. Bi eta hiru silabako erro markatugabeen azentuazioa singularrean eta pluralean

\begin{tabular}{|l|l|l|l|}
\hline Sg & Pl & Sg & Pl \\
\hline lagúne & lagúnek & alkatíe & alkátiek \\
\hline laguné da & lagúnek die & alkatíe da & alkátiek die \\
\hline lagunéi & lagúnei & alkatíei & alkátiei \\
\hline lagunéna & lagúnena & alkatíena & alkátiena \\
\hline lagunéntzako & lagúnentzako & alkatíentzako & alkátientzako \\
\hline
\end{tabular}

Bestalde, badira hitz batzuk -markatuak edo berezia- azentua lehen edo bigarren silaban daramatenak deklinabidearen forma guztietan, bai mugagabean, bai singularrean, baita pluralean ere. Hitz horiekin, beraz, singularra eta plurala ez dira bereizten azentuaren bidez: báserriye (sg), báserriyek (pl); bélarriye, bélarriyek; bílbotarrai 'bilbotarrari edo bilbotarrei'. Xehetasun gehiagorako, ikusi emandako erreferentziak. Hemengo ikerketa esperimentalerako, garrantzitsua dena da azentuaren kokagunea fonologikoki bereizgarria dela. Absolutibo eta kasu lokatiboetan izan ezik, singularra eta plurala berdinak dira beren segmentu-egituran, baina azentuazio desberdinak dituzte hitz markatugabeetan. Azentuaren ezaugarri fisikoak aztertzeko, fenomeno hori oso erabilgarria da; izan ere, segmentu aldetik berdinak bai baina azentuazioan desberdinak diren hitzak alderatu ditzakegu. 


\section{IKERKETA-GALDERAK}

Ikerlan honen helburua da Azpeitiko euskararen azentuaren gauzatze fonetikoa aztertzea. Horretarako, ohiko hiru izari edo dimentsio akustikoak hartuko ditugu kontuan; hots, soinu-uhinaren oinarrizko maiztasuna (F0) edo tonua, iraupena eta intentsitatearen garrantzia. Hiru dimentsio horiek azentuaren ezaugarri bezala erabiltzen baldin badira, bokal azentudunak azentugabeak baino luzeagoak eta indartsuagoak izango dira, eta tonu altuagoa izango dute edo tonu gorakada bat izango dute (hitza fokalizatuta dagoenean behintzat).

\section{METODOAK}

\subsection{Estimuluak eta parte-hartzaileak}

Estimuluak sortzeko, Goizuetako azentuari buruz Hualde, Lujanbio eta Torreirak (2008) idatzitako artikuluko zerrendan dauden hitz guztiak erabili ditugu, miru hitza izan ezik (Azpeitian ezezaguna delako). Hala ere, analisirako grabatutako hitz guztiak ez ditugu erabili, beherago azaltzen ditugun arrazoiengatik.

Hitz horiek singularrean eta pluralean esanarazi dizkiegu gure hiztunei, esan bezala, hitz gehienekin azentuaren kokagunea aldatu egiten baita singularrean eta pluralean. Aipatutako Goizuetako euskararen ikerketan bezala, hitzak komitatiboan erdietsi ditugu, itzulpenaren bidez. Hori horrela, esperimentuko parte-hartzaileek honelako estimulu idatziak jaso dituzte:
Estimuluak (adibideak)
Con la hija (alaba) esan det
Con los corderos (bildots) ________-_ esan det

Estimuluetan agertzen diren hitzak hauexek izan dira, hurrenkera honetan (komitatibo singularrean eta pluralean): hombre (gizon), azul (urdin), hija (alaba), oveja (ardi), berza (aza), piel (azal), hilo (hari), valle (haran), cabeza (buru), tronco (enbor), cordero (bildots), jabali (basurde), oro (urre), vaso (baso), monte (mendi), hijo (seme), carnero (ahari), madre (ama), amigo (lagun), bosque (baso), oreja (belarri). Guztira, zerrendak 42 esaldi ditu, lehen 21 esaldiak singularreko hitzekin, eta gero, hitz berak pluralean.

Sei hiztunek hartu zuten parte esperimentu honetan, bost emakumezkok eta gizonezko batek. Adinari dagokionez, lau hiztunek 23 urte zituzten, batek, 21, eta beste batek, 36 .

\subsection{Grabaketa eta analisi akustikoa}

Hiztun guztiek hurrenkera berean, behin eta ahoz itzuli dituzte esaldiak Azpeitiko euskarara. Grabaketak Azpeitian egin dira, zaratarik gabeko gela batean, MicroTrack 24/96 grabagailu bat eta Sony F-720 mikrofono dinamiko bat erabiliz. 
Soinu-uhinak ordenagailu batera pasatu ditugu eta Praat programaren bidez (Boersma \& Weenink, 2016) analizatu. Datuen segmentaziorako bi testu-lerro sortu ditugu Praaten. Lerro batean hitzak segmentatu ditugu, eta beste lerroan, bi bokal: singularrean azentua daraman bokala (V2) eta aurreko silabakoa (V1), pluralean azentua daramana, singularraren eta pluralaren arteko azentu-bereizketa duten hitzetan. 1. eta 2. irudietan bi adibide jarri ditugu, gure segmentazioa erakutsiz. Tonua edo F0 interpretatzeko, kontsonante ahoskabeek kurba apurtzen dutela kontuan hartu behar da.

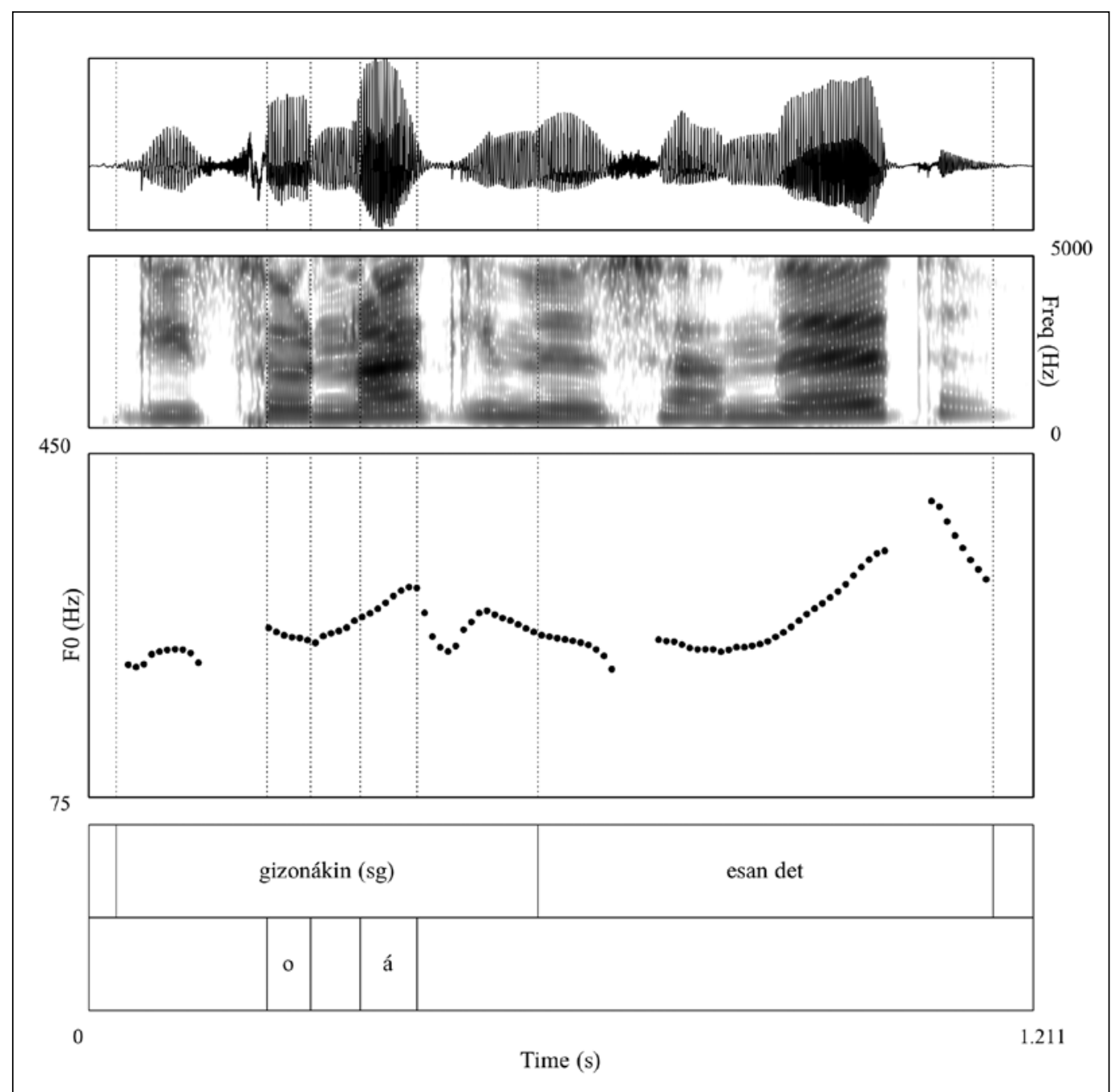

1. irudia. Gizonákin esan det 'gizonarekin esan dut' (hiztuna: 1f). Soinu-uhina, espektrograma, oinarrizko maiztasuna eta segmentazioa. 


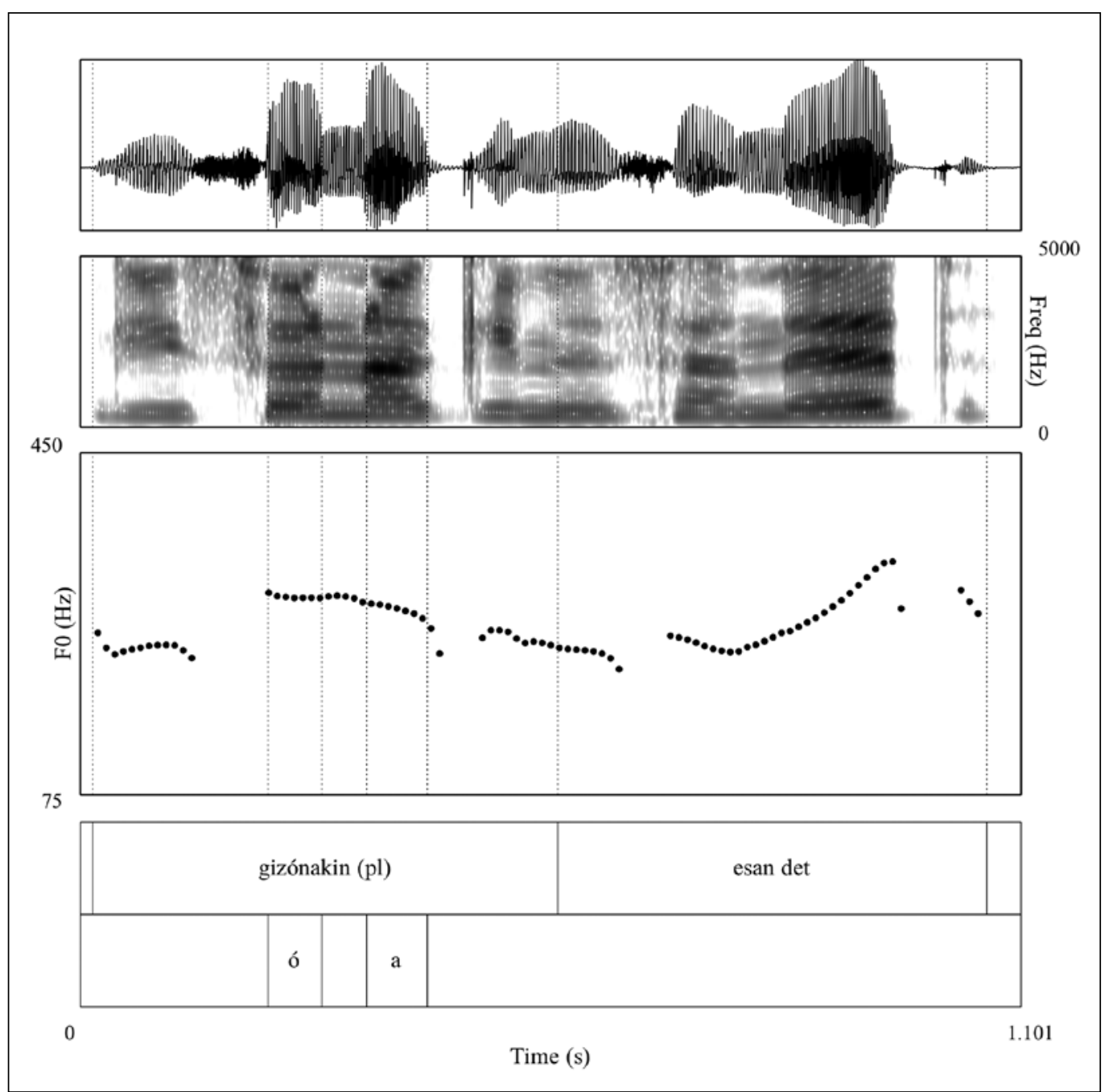

2. irudia. Gizónakin esan det 'gizonekin esan dut' (hiztuna: 1f). Soinu-uhina, espektrograma, oinarrizko maiztasuna eta segmentazioa.

Esperimentu honetarako espreski idatzitako script batekin, V1 eta V2-ko iraupena, oinarrizko maiztasuna eta intentsitatea atera ditugu. Oinarrizko maiztasun- eta intentsitate-balioa bokalaren batez bestekoa da, ez bokalak duen baliorik altuena.

Segmentazio-fase horretan grabatutako hitz batzuk analisi estatistikoan ez sartzea erabaki dugu. Hasteko, basurde eta belarri hitzetan, gure hiztunek silaba berean kokatu dute azentua singularrean eta pluralean. Hau da, hitz horiek markatuak dira hiztun guztientzat. Espero bezala, belarri hitza markatua da gure hiztunentzat, baina guztiek ez dute azentua silaba berean jarri. Lau hiztunek bélarriyekin esan dute bai singularrean, baita pluralean ere, eta beste bik belárriyekin, singularrean eta pluralean azentua hitzaren bigarren silaban kokatuz, alegia. Bestalde, basúrdi(e)kin hitz konposatuak 
azentua bigarren silaban darama singularrean eta pluralean gure sei hiztunentzat. Horretaz gain, hari hitzaren azentuazioan, aldakuntza handia ikusi dugu datuetan, eta hitz hori ere aztertutako datu-basetik kendu dugu. Horretaz gain, erroa /e/, /o/ eta /u/ bokalekin bukatzen denean, bigarren bokala galdu egin daiteke sortzen diren sekuentzietan, eta bokalaren galerak eragina izan dezake azentuaren kokagunean, adib. 'buruarekin' buruékin zein burúkin izan daiteke eta 'semearekin' semiékin edo semíkin izan daiteke. Gure hiztunek bi modu horietan ahoskatu dituzte hitzok. Gainera, bi bokalak ahoskatzen direnean ere, bi bokalen arteko muga jartzea oso zaila da askotan. Horren ondorioz, hitz horiek ez ditugu analizatu.

Hitz horiek zerrendatik kanpo utzi eta gero, hurrengo hogeita lau hitzak dira analisian sartu ditugunak (hamabi singularrean eta hamabi pluralean), 2. taulan erakusten den bezala:

2. taula. Aztertutako hitzak

\begin{tabular}{|l|l|l|}
\hline & Singularra & Plurala \\
\hline 1 & alabákin & alábakin \\
\hline 3 & amákin & ámakin \\
\hline 4 & haranákin & haránakin \\
\hline 5 & ardiyékin & ardíyekin \\
\hline 6 & azákin & ázakin \\
\hline 7 & azalákin & azálakin \\
\hline 8 & bildotsákin & bildótsakin \\
\hline 9 & enborrákin & enbórrakin \\
\hline 10 & gizonákin & gizónakin \\
\hline 11 & lagunékin & lagúnekin \\
\hline 12 & mendiyékin & mendíyekin \\
\hline
\end{tabular}

Hiztun guztiek alabákin esan zuten singularrean, eta ez alabíekin. Badirudi hiztun horientzat, behintzat, alaba hitza familiako lexikoan artikulua hartzen ez duten beste hitzak bezala (ama, aita, osaba) deklinatzen dela eta ez, /a/-z bukatzen diren hitz arruntak bezala (cf. neskié (da), elizie, enarie, kalabázie, etab.).

Zortzigarren hitz parearen kasuan, hiztun batek beste hitz bat esan zuen (adib. enbórrakin esan beharrean, trónkukin esan zuen). Beste kasu batzuetan, beste hutsegite edo akatsen bat ere gertatu zen. Horri lotuta, $a z a$ hitzaren komitatibo singularrean, bi hiztunek printzipioz /a/-z bukatzen den izen arrunt baterako espero dugun forma eman zuten, hau da, aziékin azíkin. Beste laurek, aldiz, azákin esan zuten eta azken hori da kontuan hartu dugun forma. 
Hutsegiteak eta ahoskera bereziak kenduz, 136 token geratu dira analisi estatistikorako $(12$ hitz $* 2 \mathrm{sg} / \mathrm{pl} * 6$ hiztun $=144,-7$ huts $=136$ hitz analisian $)$.

Azentuaren ezaugarri akustikoak neurtzeko V1 eta V2-ren arteko diferentziak kalkulatu ditugu hitz bakoitzean.

\section{HIPOTESIAK}

Lehenengo atalean esan bezala, orain arteko ikerketak erakutsi du Bizkaiko kostaldeko hizkeretan iraupena ez dela (ia) erabiltzen silaba azentudunak bereizteko (Elordieta $\&$ Hualde, 2003a; Hualde, Smiljanić \& Cole, 2000). Hizkera hauetan, ordea, azentu-sistema oso bestelakoa da, hitz azentudunak eta azentugabeak bereizi egiten baitira. Azpeitiko azentuazioa gaztelaniaren azentuazioarekin alderatzen dugunean, oso azentu-arau desberdinak aurkitzen baditugu ere, ez dugu zertan pentsatu azentuaren ezaugarri fisikoetan alde handiak topatuko ditugula. Beraz, gaztelaniaz bezala (ikus, adib., Ortega \& Prieto, 2010), tonua (oinarrizko maiztasuna), intentsitatea eta bokalaren iraupena azentuaren ezaugarriak izatea espero dugu gure datuetan. Hala ere, Gipuzkoako hizkera honetan, Nafarroako hizkeretan ez bezala, sinkopa eta aferesia ez direnez indartsuak, pentsatzekoa da iraupenak Goizuetan baino garrantzi txikiagoa izango duela silaba azentudunak eta azentugabeak bereizteko.

Izari fonetiko jakin bat azentu lexikalaren ezaugarri bezala erabiltzen den neurrian, silaba azentudunean beste silaban baino tamaina handiagoa izatea espero dugu. Gure datuetan silaba azentuduna V2 denez singularrean, eta V1, pluralean, V1-V2 diferentzia negatiboa izango da singularrean, eta positiboa pluralean.

Alabaina, tonuari dagokionez, garrantzitsuena tonu-mugimendua izan daiteke, eta ez tonu maila. Adibide gisa ematen ditugun 1. eta 2. irudietan ikusten den bezala, tonu-gorakada dugu silaba pretonikotik azentudunera. Beraz, gizonákin adibidean (1. irudia), gorakada /-ná-/ silabaren hitzaren hasieran hasten da, eta gizónakin adibidean (2. irudia), aldiz, /-só-/ silaban. Adibide horietan /o/ (V1) eta /a/ (V2) bokalen arteko F0 diferentzia ateratzen badugu, alde nabarmen bat ikusiko dugu 1. irudian (singularrean). Haatik, 2. irudian (pluralean) askoz apalagoa den diferentzia bat dugu bi silaba horien artean, silaba azentudunaren tonu altua mantendu egiten baita hurrengo silaban.

Hipotesiak laburbilduz, silaben arteko diferentziak bereziki esanguratsuak izango dira oinarrizko maiztasunean (F0), hori baita aurreko beste ikerketetan aurkitu dena. Bestalde, Bizkaiko kostaldeko hizkeretan ez bezala, iraupen-diferentzia esanguratsuak ere espero ditugu. Izan ere, Azpeitiko sisteman ez da egiten Bizkaiko kostaldeko hizkeren hitz azentudun eta azentugabeen arteko bereizketa. Hala ere, Azpeitian aferesi-sinkopak indartsuak ez direnez, gure hipotesia da iraupenak Goizuetako euskaraz baino pisu txikiagoa izango duela. Intentsitatean ere, diferentzia esanguratsuak espero ditugu silaba azentudunen eta azentugabeen artean. 


\section{EMAITZAK}

\subsection{Estatistika deskribatzaileak}

Hurrengo taulan (3. taula), 1. irudiko adibidean automatikoki ateratako neurketak erakusten ditugu. Esan bezala, analisi estatistikoan V1-V2 diferentziak erabili ditugu. Adibidean azentua V2n dago eta, ikusten denez, hiru diferentziak negatiboak dira.

3. taula. Neurketak (1. irudiko adibidea)

\begin{tabular}{|l|r|c|c|}
\hline giz I $\frac{\mathbf{o}}{\text { V1 }}$ I n I $\underset{\mathbf{a}}{\mathbf{a} \text { 2 }}$ I kin & \multicolumn{3}{|c|}{ 'gizonarekin' (hiztuna: 1f) } \\
\hline Iraupena (ms) & V1 /o/ & V2 /á/ & V1 - V2 \\
\hline F0 (Hz) & 55.42 & 74.84 & -19.42 \\
\hline Intentsitatea (dB) & 251.15 & 289.15 & -38.0 \\
\hline
\end{tabular}

Datu guztien batezbestekoak eta desbideratze estandarrak 4. taulan adierazi ditugu. Ikusten denez, aztertutako hiru izarietarako -iraupena (milisegundotan), oinarrizko maiztasuna (Hz-tan) eta intentsitatea (dezibeliotan)- V1-V2 diferentziak negatiboak dira singularrean (hau da, V2-k balio handiagoak ditu), eta positiboak pluralean (V1-k balio handiagoak ditu). Beste era batera esanda, bai singularrean eta baita pluralean ere, silaba azentuduna alderaketa honetan sartu dugun silaba azentugabea baino luzeagoa, tonuz altuagoa eta indartsuagoa da. Hala ere, iraupen- eta intentsitate-diferentziak oso txikiak dira.

Bi silaben arteko alderik handiena singularreko hitzen tonuan edo F0n aurkitzen dugu. Tonuari dagokionez, pluralean diferentzia txikiagoa izateak esan nahi du tonugorakada silaba azentudunean hasten dela eta gailurra hurrengo silaban kokatu daitekeela. Singularrean V1 pretonikoa da eta V2 azentuduna. Pluralean, aldiz, V1 azentuduna da eta $\mathrm{V} 2$, postonikoa.

4. taula. V1-V2 diferentziak: batezbestekoak (desbideratze estandarra)

\begin{tabular}{|l|c|c|}
\hline & Singularrak & Pluralak \\
\hline Iraupena $(\mathrm{ms})$ & $-1.52(17.80)$ & $0.35(21.83)$ \\
\hline F0 $(\mathrm{Hz})$ & $-37.34(16.79)$ & $4.89(10.06)$ \\
\hline Intentsitatea $(\mathrm{dB})$ & $-1.25(2.31)$ & $0.85(2.57)$ \\
\hline
\end{tabular}

Batezbestekoak ikusita, argi dago F0 ezaugarririk garrantzitsuena dela, singularren eta pluralen balioak oso desberdinak baitira izari honetan. Singularrean, bigarren bokaleko tonua lehen bokalekoa baino askoz altuagoa da, batezbesteko diferentzia 37 Hz-koa delarik. Pluralean lehen bokaleko tonua apur bat altuagoa da, baina diferentzia ez da oso handia, batez beste $5 \mathrm{~Hz}-\mathrm{koa}$, gutxi gorabehera. 
Iraupenean, aldiz, bi taldeen arteko aldea oso txikia da, bereziki desbideratze estandarrak askoz handiagoak direla kontuan hartzen badugu. Beraz, ez dirudi izari honek azentuaren kokagunea adierazteko balio duenik.

Azkenik, intentsitateko diferentziak ere txikiak dira. Azterketa estatistiko sakonagoa egin behar dugu diferentziak esanguratsuak diren ala ez jakiteko.

Iraupenaren emaitzak 3. irudian erakusten dira kutxa-grafikoetan. Grafiko hauetan, marra lodia mediana da, eta kutxek eta marrek datuen banaketa erakusten dute, pluralean eta singularrean. Ikusten denez, ez dirudi alde handirik dagoenik singularren eta pluralen artean, bi kutxak ia osorik gainjartzen baitira.

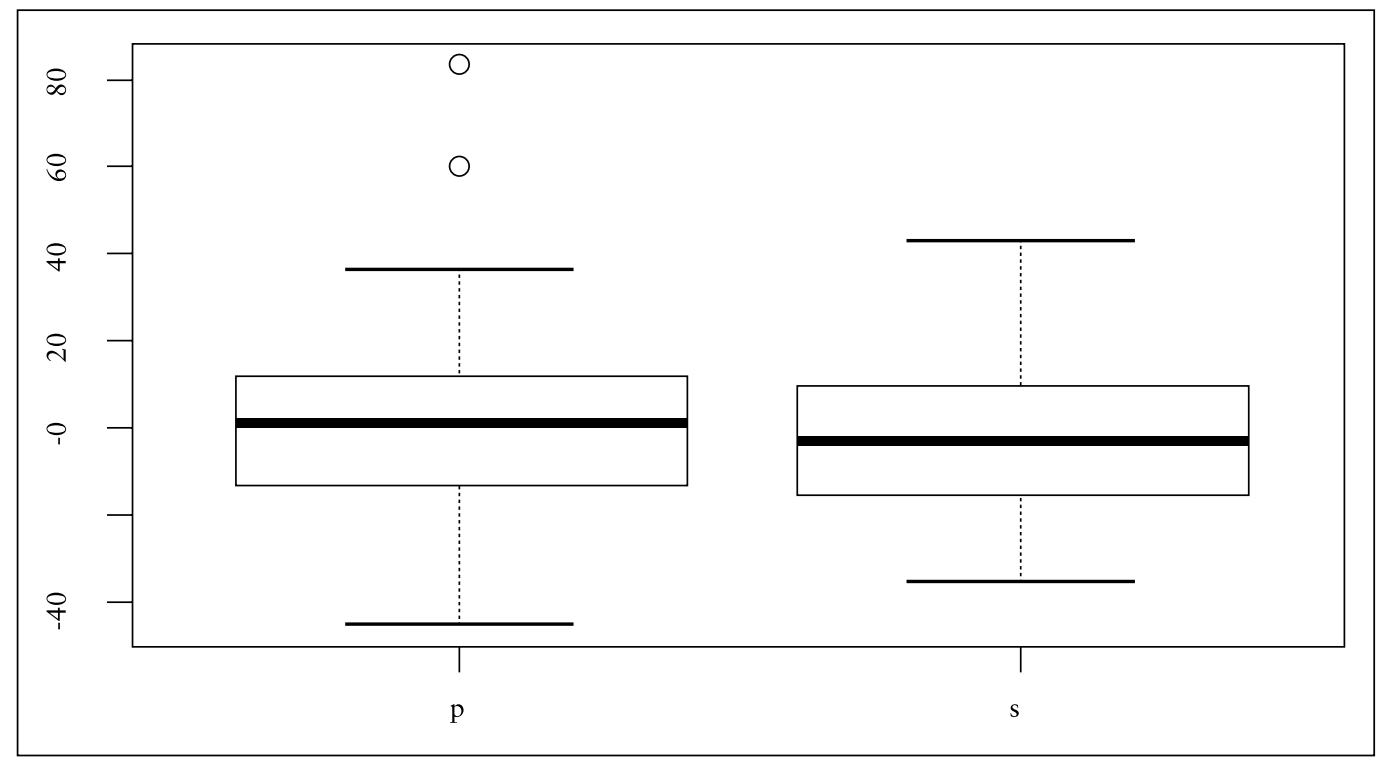

3. irudia. Iraupen-diferentziak (V1-V2), ms-tan; $\mathrm{p}=$ pluralak, $s=$ singularrak.

Neurtutako bi silaben arteko oinarrizko maiztasun diferentziak 4. irudiko kutxagrafikoan erakutsi dira. Irudiari erreparatuz gero argi dago izari honetan singularrak eta pluralak oso desberdinak direla. 


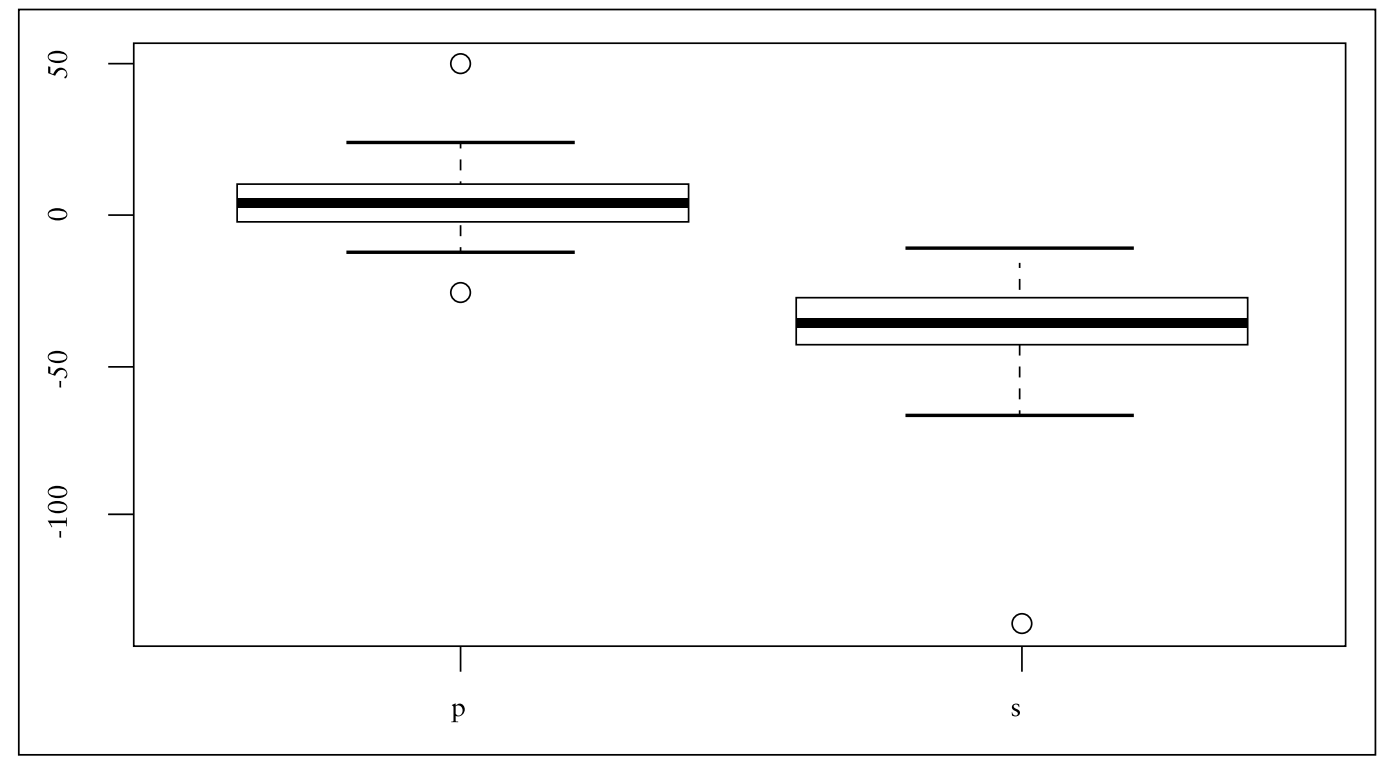

4. irudia. F0 diferentziak (V1-V2), Hz-tan.

Intentsitatearen neurketen banaketa 5. irudian erakusten da. Nahiz eta balio absolutuetan singularraren eta pluralaren arteko aldea oso handia ez izan, bereizketa iraupen balioena baino garbiagoa da.

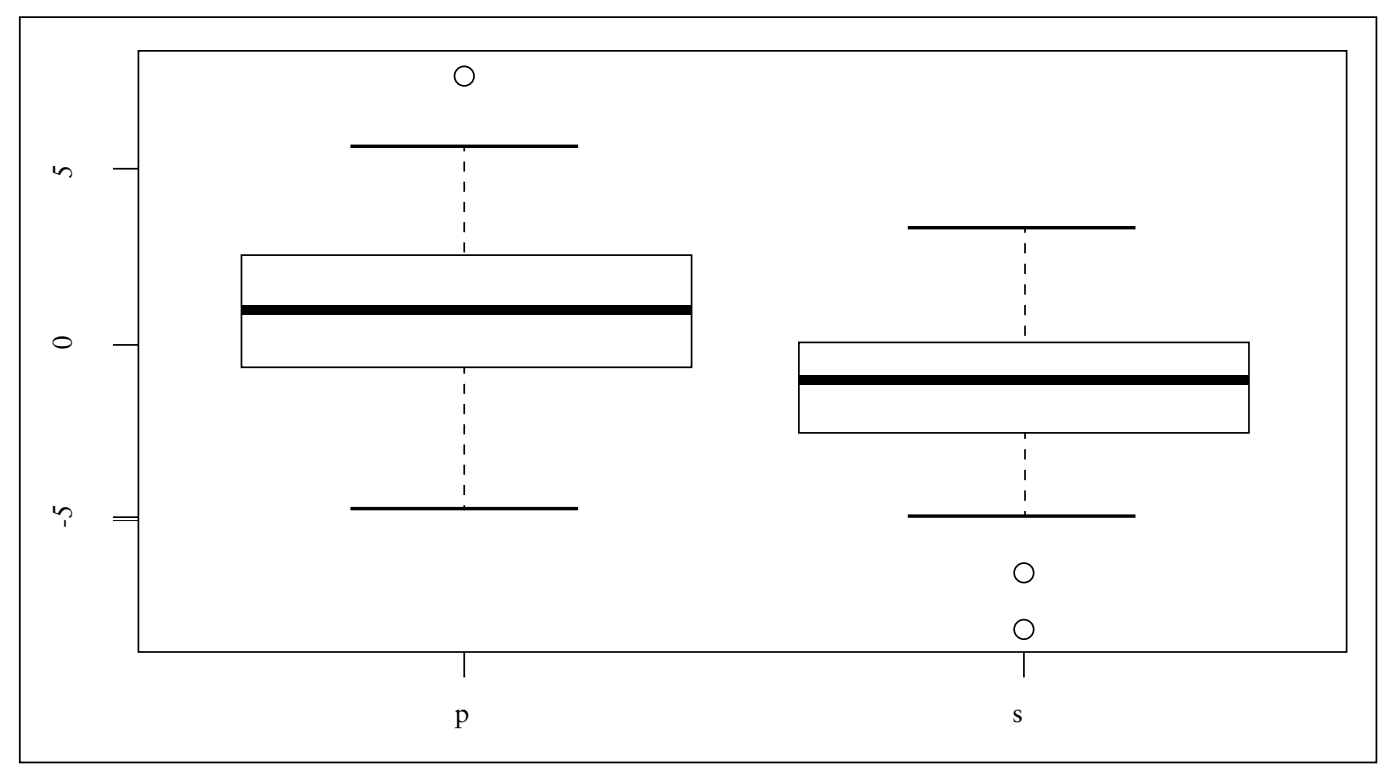

5. irudia. Intentsitate-diferentziak (V1-V2), dB-tan. 
Laburtuz, 3.-5. irudietan ikusten den bezala, singularraren eta pluralaren arteko desberdintasunik handiena F0-n dago. Singularreko eta pluraleko datuak oso ondo bereizten dira tonuaren bidez. Intentsitatean, singularraren eta pluralaren kutxek gainjartze handiagoa erakusten dute. Iraupenean, ez dago begi-bistako diferentziarik.

\subsection{Estatistika inferentzialak}

Goiko 4. taulan eta 3.-5. irudietan ikusten diren singularraren eta pluralaren arteko desberdintasunak estatistikoki esanguratsuak diren aztertzeko, linear mixed effects regression analisiak erabili ditugu, lme4 (Bates et al., 2014) eta lmerTest (Kuznetsova, 2015 ) paketeak erabiliz $R$ estatistika programan (R Core Team, 2016). $R$ Studio interfaze grafikoarekin (R Studio Team, 2016).

Hiru izariak, hots, iraupena, oinarrizko maiztasuna eta intentsitatea, 6.1. atalean jarraitu dugun hurrenkera berean aurkeztuko ditugu atal honetan ere.

Lehenengo analisian V1-V2 iraupen-diferentzia jarri dugu mendeko aldagai gisa (scale \& center funtzioaren bidez transformatuta). Hiru faktore tinko (fixed factors) sartu ditugu analisian: zenbaki gramatikala (singularra edo plurala), V1-eko identitatea eta hiztunaren sexua. Nahiz eta benetan interesatzen zaiguna zenbaki gramatikalaren eragina den (hau da: azentua V1-en edo V2-n dagoen), beste bi faktoreek ere eragina izan dezakete, eta hau ere kontuan hartu behar da analisian.

Oro har, gauza jakina da baldintza berberetan beheko bokalak goikoak baino luzeagoak direla. Gure datuetan, V2 beti /a/ edo /e/ da. Alabaina, V1 posizioan aldakortasun handiagoa dugu: /a/, /o/, /i/, /u/. Arrazoi horrengatik, lehenengo bokalaren identitatea gure erregresio-analisian faktore gisa sartu dugu.

Gizonezko hiztun bakar bat dugu eta iraupenean sexuak ez luke eragin handirik izan behar. Hala ere, $\mathrm{F} 0$-n eragin handia izan dezakeenez, faktoreen artean sartu dugu erregresio analisi guztietan.

Aldagai aleatorio (random factors) modura hiztuna eta hitza sartu ditugu, hala hiztun desberdinek eta hitz desberdinek eragindako aldakortasuna kontrolatuz, hemen erakusten den formula erabiliz:

Linear Mixed Effects Regression (iraupena)

lmer(scale(A7\$durDiff)

$\sim$ A7 \$sgpl+A7\$v1qual+A7\$gender+(1lA7\$speaker)+(1|A7\$word))

Non: durDiff = V1-en iraupena ken V2-rena; sgpl = hitza singularra ala plurala den; v1qual = V1 /a/, /i/, /o/ ala /u/ den; gender= hiztunaren sexua; speaker = hiztuna (A7 datu-orriari eman diogun izena da) 
Iraupenaren erregresioko emaitzek adierazten dute singular/plural sailkapen bitarrak ez duela eragin esanguratsurik bokalen iraupenean $(\mathrm{p}=0.56)$, eta hiztunen sexuak ere ez. Aldiz, V1-en nolakotasunak eragin esanguratsua du. Zehazkiago esanda, erregresioak erakusten du V1-en eta V2-ren arteko erlazioa desberdina dela V1 /a/ denean eta /i/ denean $(\mathrm{p}=0.0001)$. Gure helburuetarako garrantzitsuena da iraupenak ez duela laguntzen singularrak eta pluralak bereizteko eta, beraz, ez digula esaten azentua V1-en ala V2-n dagoen. Beraz, 4. taulan ikusten diren batezbestekoen diferentzia txikiak ez dira esanguratsuak.

Bigarren analisi bat egin dugu, goiko formularekin, baina mendeko aldagai modura V1-V2 F0-ko diferentziak sartuz, iraupen-diferentzien ordez. Erregresioaren emaitzek erakusten digute sg/pl sailkapen bitarrak oso eragin esanguratsua duela F0 edo tonuan ( $\mathrm{p}<0.0001)$. Hiztunaren sexuak ere garrantzia du, uste bezala $(\mathrm{p}=0.05)$ eta V1-en nolakotasunak, aldiz, ez du eraginik. Tonua ere agertzen zaigu, beraz, azentuaren ezaugarri garrantzitsu bezala, 4. taulan eta 4. irudian ikusten dena baieztatuz.

Azkenik, erregresioa errepikatu dugu, bi bokalen arteko intentsitate-diferentziekin. Izari honetan ere, singular/plural sailkapenak eragin esanguratsua du emaitzetan ( $\mathrm{p}<0.001)$. Hiztunaren sexuak ez du eraginik, eta, kasu honetan, /a/-/o/ alderaketa V1-ean esanguratsua da $(\mathrm{p}=0.01)$. Beraz, intentsitateak ere azentuaren kokagunea adierazteko balio du.

\section{LABURPENA}

Gure esperimentuaren emaitzek erakutsi digute Azpeitiko euskaran tonua edo F0 erabiltzen dela azentuaren ezaugarri akustiko bezala. Horretaz gain, intentsitatea ere erabiltzen da silaba azentudunei indarra emateko. Bestalde, iraupena ez da azentuaren ezaugarri esanguratsua, guk uste ez bezala. Alde horretatik badirudi Azpeitiko euskararen azentua ez dela guztiz gaztelaniarena bezalakoa, are gutxiago Goizuetakoa bezalakoa. Aldiz, Azpeitiko euskara Bizkaiko kostaldeko doinu-azentu sistemara hurbiltzen da aspektu horretan. Bizkaiko euskal hizkera horietan bezala, tonua da azentuaren adierazle nagusia (Elordieta \& Hualde, 2003a; Hualde, Elordieta, Gaminde \& Smiljanić, 2002).

Hala ere, azentuari lotutako tonu-mugimenduak desberdinak dira bi hizkeretan. Bizkaiko doinu-azentu hizkeretan, tonu aldaketarik nabarmenena silaba azentudunaren eta hurrengo silabaren artean agertzen da: tonu-gailurra dugu azentudunean, eta beherakada azkarra, hurrengo silaban. Fonologikoki esan daiteke azentua $\mathrm{H}^{*} \mathrm{~L}$ kontornu bat dela (Elordieta, 1997; Jun \& Elordieta, 1997).

Azpeitiko datuetan, berriz, ikusi dugu bi bokalen arteko F0-ko aldea handia dela azentuduna V2 denean, eta askoz apalagoa azentua V1-ean dagoenean. Hau da, tonugorakada dugu silaba azentudunean eta tonu maila mantendu egin daiteke hurrengo silaban. Fonologikoki LH* izango genuke, hau da, gaztelanian eta Gipuzkoako beste euskal hizkera batzuetan bezala (Elordieta, 2011a). Beste era batera esanda, Lekeition, Ondarroan edo Bermeon, tonu beherakada bat dugu silaba azentudunaren eta hurrengo silabaren artean. Horrela adierazten da azentugunea non dagoen. Azpeitian, aldiz, garrantzitsuena silaba azentuduneko tonu-gorakada da. 


\section{ONDORIOAK: EUSKAL AZENTUAREN BILAKAERA ETA SEGMENTU-FONOLOGIA}

Badira arrazoiak pentsatzeko gaur egun Bizkaiko kostaldean aurkitzen dugun doinuazentu sistema orokorragoa zela duela zenbait mende (Hualde, 2006). Sistema horretan, tonu-beherakada azentuarekin lotzen da, eta tonu-gorakadek, berriz, talde prosodikoen hasierako mugak adierazten dituzte. Tonu-mugimenduak berrinterpretatu egin ziren garai eta leku desberdinetan, bigarren silabako azentu-araua sortuz eta hitz azentudunen eta azentugabeen arteko bereizketa galduz (Elordieta \& Hualde, 2003b; Hualde, 2003).

Urolaldeko euskararen azentu-arau nagusia, azentua hirugarren silaban egotea, oso maiztasun gutxikoa da munduko hizkuntzetan (Hualde, 1998). Azentuazio hori ere jatorrizko sistematik beste bilakaera baten bidez sortu omen zen (Hualde, 2003). Hemen aztertutako esaldi deklaratiboetan, behintzat, azentu nagusia goranzko tonu baten bidez gauzatzen da, Gipuzkoako beste zenbait hizkeratan bezala (Elordieta, 2011). Goizuetan ere goranzko tonua azentu ez-markatuarena da, baina Nafarroako hizkera horretan badago doinu-bereizketa lexikal bat, hitz markatuek beheranzko tonua daramatelako.

Ikusi dugunez, beste ezberdintasun garrantzitsu bat iraupenaren funtzioan datza. Nolabait eta noizbait iraupena azentuaren ezaugarri bezala hasi zen erabiltzen Nafarroako euskaran, silaba azentuduna luzatzen eta azentugabeak murrizten hasiz. Gipuzkoan, ordea, hori ez zen gertatu. Horren ondorioz, azentuarekin lotura duten honako bi segmentu-fenomeno hauek kausitzen ditugu ekialdean, baina ez mendebaldeko edo erdialdeko euskalkietan:

(a) Bokal azentugabe batzuen galera, hau da, aferesia (hitzaren hasierako bokalen galera, adib., emán > man) eta sinkopa (hitz-barneko bokalen galera, adib., gánbara $>$ ganbra).

(b) Hiatoen diptongazioa (adib., mendi.a > mendia).

Biak ala biak ekialdeko fenomenoak, edo, nahi bada, Nafarroakoak badira ere, beren eremu geografikoak ez dira berdinak eta, ziur asko, biak ez dira garai berekoak. Diptongazioaren isoglosa Bortziriren eta Baztanen artetik igarotzen da (Hualde \& Gaminde, 1998) eta, beraz, badirudi azentu-arau nagusiaren aldakuntza batekin zerikusia duela, ekialdeko [+2] > [-2] aldakuntzaren isoglosa leku berean kokatzen baita. Bortzirin azentua normalean bigarren silaban doa ([+2], adib., larúnta «larunbata») eta Baztanen, aldiz, azken-bigarrenean ([-2], adib. launbéta).

Hiatoen diptongazioaz bezainbatean, Pirinioetako hegoaldetik, Erronkariraino heldu bazen ere, ez zen hedatu Zuberoara (adib., Erronk. méndịa vs Zub. mendía) ${ }^{1}$.

1 Deklinabidean sortzen diren [ịa] bezalako goranzko diptongoez ari gara. Zubererak badauzka beste diptongo (eta triptongo) mota batzuk. Partikularzki, dardarkari leunaren galerak diptongo berriak sortu ditu, adib., laborari [laßuai]. 
Bokal azentugabeen galerak diptongazioak baino zabalera handiagoa du Nafarroan, ia Gipuzkoako mugan dagoen Goizuetan ere ematen baita. Gainera, zaharragoa dirudi zenbait eskualdetan behintzat, Mitxelenak (1977: 399 = 2011: 325) esaten digunez, Nafarroako lehen testuetatik dokumentatzen baita. Dena den, hizkera guztietan bokalen galerak ez du indar edo maiztasun bera eta badirudi hizkera batzuetan ez dela hain zaharra. Bereziki, zaraitzueraz eta erronkarieraz, eta baita ere Bortzirietako Arantzako hizkeran, oso sinkopa bortitzak aurkitzen ditugu. Hala ere, honek ez digu esaten fenomenoa non hasi zen edo nondik zabaldu zen.

Esan bezala, noizbait, historiako uneren batean, iraupenak indarra hartu zuen Nafarroako euskaran azentuaren ezaugarri bezala. Bokal azentudunak luzatzen hasi ziren eta alboko azentugabeak laburtzen; horren ondorioz, haiek eroriz. Aldakuntza fonetiko horrek oso garrantzi handia izan du Nafarroako euskararen bilakaeran. Urolaldeko gipuzkeraz, aldiz, ez dirudi iraupenak balio handirik duenik azentuaren adierazle akustiko modura.

Oraindik ez dago batere garbi nola aldatzen diren azentuaren ezaugarriak hizkuntza baten bilakaera diakronikoan. Azentuaren izari fonetikoen azterketak gertakari horiek ulertzen lagundu diezaguke, hemen egindako lana Gipuzkoako eta Nafarroako beste hizkera batzuei aplikatuz. 


\section{ERREFERENTZIAK}

Altuna, P. (1985). Azpeitiko euskal ebakeraz. Euskera, 31(2), 333-340.

Azkue, R. M. D. (1931). Del acento vasco en algunos de sus dialectos. Euskera, 4, 282-318.

Azkue, R. M. (1932). Del acento vasco en algunos de sus dialectos. Euskera, 6, 3-50.

Bates, D., Maechler, M., Bolker, B. \& Walker, S. (2014). lme4: Linear mixed-effects models using Eigen and S4. R package version 1.1-7. Hemendik hartua: http://CRAN.R-project.org/package $=1 \mathrm{me} 4$

Beristain, A. (prestatzen). Azpeitiko euskararen hiztegi dialektal bat. Urbana-Champaign: University of Illinois.

Bethin, C. (1998). Slavic prosody: Language change and phonological theory. Cambridge: Cambridge University Press.

Boersma, P. \& Weenink, D. (2016). Praat: doing phonetics by computer, version 6.021 [computer program].

Bruce, G. (1977). Swedish word accents in sentence perspective. Travaux de l'institut de linguistique de Lund, 12.

Egurtzegi, A. \& Elordieta, G. (2013). Euskal azentueren historiaz. In R. Gómez, J. Gorrochategui, J. A. Lakarra \& C. Mounole (arg.), Koldo Mitxelena Katedraren III. Biltzarra (163-186 orr.). Gasteiz: UPV/EHU. (Koldo Mitxelena Katedraren Argitalpenak, 5).

Elordieta, G. (1997). Accent, tone, and intonation in Lekeitio Basque. In F. MartínezGil, \& A. Morales-Front (arg.), Issues in the Phonology and Morphology of the Major Iberian Languages (3-78 orr.). Washington, DC: Georgetown University Press.

Elordieta, G. (2011a). Basque word accents in the sentence. In G. Aurrekoetxea \& I. Gaminde (arg.), Prosodiaz eta Hezkuntzaz I. Jardunaldiak (47-62 orr.). Bilbo: UPV/EHU.

Elordieta, G. (2011b). Euskal azentuaren bilakaera: hipotesiak eta proposamenak. In Euskaltzaindiaren XVI. Biltzarra: Pirinioetako hizkuntzak: lehena eta oraina (989-1014 orr.) (Iker, 26).

Elordieta, G., Gaminde, I., Hernáez, I., Salaberria, J., \& Martin de Vidales, I. (1999). Another Step in the Modeling of Basque Intonation: Bermeo. In TSD '99 Proceedings of the Second International Workshop on Text, Speech and Dialogue (361-364 orr.). London: Springer Verlag.

Elordieta, G. \& Hualde, J. I. (2003a). Tonal and durational correlates of accent in context of downstep in Lekeitio Basque. Journal of the International Phonetic Association, 33, 195-209.

Elordieta, G. \& Hualde, J. I. (2003b). Experimental test of a hypothesized diachronic change in Basque accentuation. In M. J. Solé, D. Recasens \& J. Romero (arg.), Proceedings of the 15th International Congress of Phonetic Sciences (67-70 orr.), Barcelona: Futurgraphic. [Berrarg. In Lakarra, J. A., \& Hualde, J. I. (arg.). (2006). Studies in Basque and Historical Linguistics in Memory of R. L. Trask, ASJU, 40 (1-2), 293-301].

Gaminde, I. (1993). Bermeoko azentu ereduaz. Uztaro, 8, 105-117.

Gaminde, I. (1995a). Zubereraren azentuaz. Uztaro, 13, 107-128. 
Gaminde, I. (1995b). Gipuzkeraren azentuaren azterketa akustikoa, FLV, 69, 297-321.

Gaminde, I. (1998). Euskaldunen azentuak. Bilbo: Labayru Ikastegia.

Godjevac, S. (2000). An autosegmental/metrical analysis of Serbo-Croatian intonation.

Ohio State University Working Papers in Linguistics, 54, 79-142.

Gussenhoven, C. (1999). Tone systems in Dutch Limburgian dialects. In S. Kaji (arg.), Proceedings of the Symposium on Cross-Linguistic Studies of Tonal Phenomena: Tonogenesis, Typology, and Related Topics (127-143). Tokyo: Institute for Languages and Cultures of Asia and Africa, Tokyo University of Foreign Languages.

Gussenhoven, C. (2000). On the origin and development of the Central Franconian tone contrast. In A. Lahiri (arg). Analogy, levelling and markedness: Principles of change in phonology and morphology (215-260 orr.). Berlin: Mouton de Gruyter.

Gussenhoven, C. (2004). The phonology of tone and intonation. Cambridge: Cambridge University Press.

Haraguchi, S. (1977). The Tone Pattern of Japanese: An Autosegmental Theory of Tonology. Tokyo: Kaitakusha.

Horrocks, G. (1997). Greek: A history of the language and its speakers. London \& New York: Longman.

Hualde, J. I. (1997). Euskararen azentuerak. Donostia \& Bilbao: Gipuzkoako Foru Aldundia \& UPV/EHU. (ASJU-ren Gehigarriak, 42).

Hualde, J. I. (1998). A gap filled: Postpostinitial accent in Azkoitia Basque, Linguistics, 36, 99-117.

Hualde, J. I. (1999). Basque accentuation. In van der Hulst, H. (arg.), Word prosodic systems in the languages of Europe (947-993 orr.). Berlin: Mouton de Gruyter.

Hualde, J. I. (2003). From phrase-final to post-initial accent in Western Basque. In P. Fikkert \& H. Jacobs (arg.), Development in prosodic systems (249281 orr.). Berlin: Mouton de Gruyter.

Hualde, J. I. (2006). Laringalak eta euskal azentuaren bilakaera. In B. Fernández \& I. Laka (arg.), Andolin gogoan: Essays in honour of Professor Eguzkitza (497-511 or.). Bilbo: UPV/EHU.

Hualde, J. I. (2012). Two Basque accentual systems and the notion of pitch accent language. Lingua, 122, 1335-1351.

Hualde, J. I. \& Bilbao, X. (1991). A Phonological Study of the Basque Dialect of Getxo. Donostia: Gipuzkoako Foru Aldundia (ASJU-ren Gehigarriak).

Hualde, J. I., Elordieta, G. \& Elordieta, A. (1994). The Basque Dialect of Lekeitio, Bilbo \& Donostia: UPV/EHU \& Gipuzkoako Foru Aldundia. (ASJU-ren Gehigarriak).

Hualde, J. I., Elordieta, G., Gaminde, I. \& Smiljanić, R. (2002). From pitch-accent to stress-accent in Basque. In C. Gussenhoven, \& N. Warner (arg.), Laboratory Phonology VII (547-584 orr.). Berlin: Mouton de Gruyter.

Hualde, J. I. \& Gaminde, I. (1998). Vowel interaction in Basque: A nearly exhaustive catalogue. Studies in the Linguistic Sciences, 28 (1), 41-77.

Hualde, J. I., Lujanbio, O. \& Torreira, F. (2008). Lexical tone and stress in Goizueta Basque. Journal of the International Phonetic Association, 38 (1), 1-24. 
Hualde, J. I. \& Riad, T. (2014). Word accent and intonation in Baltic. In N. Campbell, D. Gibbon, \& D. Hirst (arg.), Speech prosody 7 (668-672 orr.). Dublin. Hemendik hartua: http://fastnet.netsoc.ie/sp7/sp7book.pdf

Hualde, J. I., Smiljanić, R. \& Cole, J. (2000). On the accented/unaccented distinction in Western Basque and the typology of accentual systems. Proceedings of Berkeley Linguistic Society, 26, 133-144.

Jacobsen, W. (1972). Nominative-ergative synchretism in Basque, ASJU, 6, 67-109.

Jun, S. A. \& Elordieta, G. (1997). Intonational Structure of Lekeitio Basque. In A. Botinis, G. Kouroupetroglou \& G. Carayiannis (arg.), Intonation: Theory, Models and Applications. Proceedings of an ESCA Workshop (193-196 orr.). Atena, Grezia: ESCA.

Kariņš, A. K. (1997). Lexical tone and stress in Latvian. Berkeley Linguistics Society, 23, 186-197.

Kubozono, H. (1993). The organization of Japanese prosody. Tokyo: Kurosio.

Kuznetsova, A. (2015). lmerTest: Tests in Linear Mixed Effects Models. Version 2.025. Hemendik hartua: http://cran.r-project.org/web/packages/ lmerTest/ index.html

Larrasquet, J. (1928). Action de l'accent dans l'évolution des consonnes étudiée dans le basque souletin. Paris: Vrin.

Lujanbio, O. (argitaratzeke). Goizuetako hiztegia. ASJU.

Mitxelena, L. (1977). Fonética histórica vasca, (2. arg). Donostia: Gipuzkoako Foru Aldundia. (ASJU-ren Gehigarriak). [Berrarg. (2011). Obras completas, VI].

Mitxelena, L. (2011). Obras completas, I-XV (Lakarra, J. A. \& Ruiz Arzalluz, I., arg.). Gasteiz \& Donostia: UPV/EHU \& Gipuzkoako Foru Aldundia.

Ortega, M. \& Prieto, P. (2010). Acoustic correlates of stress in Central Catalan and Castilian Spanish. Language and Speech, 54(1), 73-97.

Pierrehumbert, J. \& Beckman, M. (1988). Japanese tone structure. Cambridge, Massachusetts: MIT.

R Core Team. (2016). R: A language and environment for statistical computing. Vienna, Austria: R Foundation for Statistical Computing. URL $<$ https:// www.R-project.org>.

Riad, T. (2012). Culminativity, stress and tone accent in Central Swedish. Lingua, 112(13), 1352-1379.

RStudio Team. (2016). RStudio: Integrated Development for R. RStudio, Inc., Boston, MA URL http://www.rstudio.com.

Smiljanić, R. (2006). Early vs late focus: peak alignment in two dialects of Serbian and Croatian. In Goldstein, L., Whalen, D. H., \& Best, C. T. (arg.), Papers in Laboratory Phonology 8 (495-518 orr.). Berlin: Mouton de Gruyter.

Zuazo, K. (2014). Euskalkiak. Donostia: Elkar. 
0000 